\title{
Leaf phenology and morphofunctional variation in Myrcia amazonica DC. (Myrtaceae) in gallery forest and "campo rupestre" vegetation in the Chapada Diamantina, Brazil
}

\author{
Aline Cristina da Silva Moraes ${ }^{1} \cdot$ Angela Pierre Vitória $^{2}$ • Davi Rodrigo Rossatto ${ }^{3}$. \\ Lia d'Afonsêca Pedreira de Miranda ${ }^{4} \cdot$ Ligia Silveira Funch ${ }^{4}$
}

Received: 7 September 2016/Accepted: 5 December 2016/Published online: 30 January 2017

(C) Botanical Society of Sao Paulo 2017

\begin{abstract}
Myrcia amazonica DC. occurs in gallery forest and "campo rupestre" vegetation in the Chapada Diamantina, Bahia State, Brazil—habitats with contrasting irradiance and humidity conditions. We evaluated variations in aspects of the cost-benefit relationships of leaf maintenance and photosynthetic activity (phenology, leaf age, gas exchange, and photosynthetic pigments) and the maintenance of a positive water balance (leaf water potential, wood density, and leaf attributes) in two populations of M. amazonica occurring in those habitats. Our hypothesis was that this species would show more efficient water use associated with maintaining its leaves for longer periods in "campo rupestre" vegetation rather than in gallery forests-linked to the environmental constraints on "campo rupestre" population (lower water availability and
\end{abstract}

Electronic supplementary material The online version of this article (doi:10.1007/s40415-016-0348-x) contains supplementary material, which is available to authorized users.

Ligia Silveira Funch

ligiafunch@yahoo.com

1 Instituto Federal de Educação, Ciência e Tecnologia da Bahia - Campus Irecê, Rodovia BA 148, km 04, No. 1800 - Bairro Vila Esperança, Irecê, BA 44900-000, Brazil

2 Laboratório de Ciências Ambientais, Centro de Biociência e Biotecnologia, Universidade Estadual do Norte Fluminense (UENF) "Darcy Ribeiro", Av Alberto Lamego, 2000, Campos dos Goytacazes, RJ 28013-602, Brazil

3 Departamento de Biologia Aplicada a Agropecuária, Universidade Estadual Paulista Júlio de Mesquita Filho, Via de Acesso Prof. Paulo Donato Castellane S/N Zona Rural, Jaboticabal, SP 14884-000, Brazil

4 Departamento de Ciências Biológicas, Universidade Estadual de Feira de Santana, Av. Transnordestina, S/N, Novo Horizonte, Feira de Santana, BA 44036-900, Brazil elevated irradiance). We found that individuals growing in "campo rupestre" showed greater stomatal conductance, $\mathrm{CO}_{2}$ assimilation, transpiration rates, leaf thicknesses, leaf succulence, daily water potential amplitudes, and leaf longevity but lower wood densities as compared to the gallery forest population. Even with wide contrasts in terms of all of these parameters, both populations maintained perennial leaf patterns, despite with variations in the intensities and durations of leaf production (being more intense and of shorter duration in the "campo rupestre" population). Myrcia amazonica demonstrated high functional and morphological plasticity of attributes related to its survival and growth in these habitats. Our hypothesis was confirmed, as "campo rupestre" plants showed morphofunctional strategies associated with resource conservation, including more efficient water use.

Keywords Gas exchange - Phenodynamics .

Photosynthetic pigments - Water potential - Wood density

\section{Introduction}

Plant survival is closely linked to the capacity to adapt to varying environmental conditions (Singh and Kushwaha 2005), which, in turn, is facilitated by plasticity of their morphological (Bloor and Grubb 2004) and/or physiological traits (Sultan 2000; Valladares et al. 2000; Gamage et al. 2003; Vieira et al. 2015; Vitória et al. 2016). This plasticity facilitates the occupation of a wide variety of microhabitats and amplifies the use of ecological niches (Ganie et al. 2014). Morphofunctional adjustments to physical variations in habitat conditions reflect different adaptive strategies related to resource acquisition and use (such as water, nutrients, irradiance, and $\mathrm{CO}_{2}$ ) (Valladares et al. 
2000; Bloor and Grubb 2004; Singh and Kushwaha 2005; Rodríguez-Garcia and Bravo 2013). Variations in phenotypic characteristics (such as their degrees of stomatal opening and photosynthetic rates) allow plants to grow and reproduce satisfactorily in a wide spectrum of sites and adjust to niche variations in irradiance and water availability (Sultan 2000).

Resistance to embolism is a fundamental parameter for determining adaptation to varying conditions of water availability, sunlight exposure, and vapor pressure deficits (VPD) (Wortemann et al. 2012). This capacity will define the limits of stomatal closing-resulting in photosynthetic limitations with increasing temperatures and irradiance, with the consequent utilization of carbohydrate reserves over time (Pockman et al. 1995; Choat et al. 2012). In habitats with high VPD, plants reduce their hydraulic conductivity by limiting water flow to the stomatal guard cells-resulting in turgor loss in those cells and consequent reductions in stomatal conductivity (Sinclair et al. 2008). Stomatal regulation is therefore necessary to maintain plant water status above the point of turgor loss (Sperry 2000), but will undoubtedly influence gas exchange (Xue et al. 2004).

Studies focusing on variations in the physiological attributes of plants according to environmental conditions have been performed with a number of species (Boardman 1977; Chazdon 1986; Chen and Klinka 1997; Murchie and Horton 1997; Naramoto et al. 2006; Sinclair et al. 2008; Rodríguez-Garcia and Bravo 2013; Rossatto et al. 2013; Puglielli et al. 2015; Vieira et al. 2015; Vitória et al. 2016) and have demonstrated that populations established in environments with high solar irradiation have thicker leaves, with higher rates of gas exchange. Studies of morphofunctional traits have examined leaf renewal, leaf age, and wood density associated with habitat heterogeneity (Goulart et al. 2005; Lemos Filho et al. 2008; Toledo et al. 2012; Capuzzo et al. 2012). Attributes such as phenology, leaf age, gas exchange, photosynthetic pigments, water potential, wood density, and leaf morphological attributes (thicknesses, succulence, density, and leaf mass per area) have been correlated with environmental conditions such as irradiance, VPD, and water balance (Rosado and de Mattos 2007; Meinzer et al. 2009; Rosado et al. 2013; Rossatto et al. 2013; Braga et al. 2016).

The heterogeneity of habitats in the Chapada Diamantina Mountains (the northeastern extension of the Espinhaço Range in central-eastern Brazil) has been the subject of numerous floristic studies of vegetation mosaics associated with wide physiographic spectra, including "cerrado" (neotropical savanna), "campo rupestre" (open, rocky fields), forests, and "caatinga" (seasonally dry, thorny, deciduous shrub/arboreal tropical forest) (Funch et al. 2009). Contrasting habitats in terms of water availability and solar radiation (such as "campo rupestre" and gallery forest) occur relatively close to one another under similar macroclimatic conditions in this vegetation mosaic (Neves et al. 2016). "Campo rupestre" vegetation predominates at altitudes over $900 \mathrm{~m}$ and represents a complex vegetation type with numerous microhabitats on rocky mountain tops growing on thin sandy soils, exposed to high solar radiation throughout the year, and experiencing water restrictions and a marked climatic seasonality (Conceição et al. 2007). Gallery forests, by contrast, occupy relatively narrow and humid bands along river margins and show continuously evergreen canopies (Funch et al. 2002).

The present study is part of an investigation of the morphofunctional variations observed among some Myrtaceae species distributed from gallery forest (450 m a.s.l.) sites to "campo rupestre" areas at elevations near $1000 \mathrm{~m}$ a.s.1. in the Chapada Diamantina Mountains. Here we provide information about Myrcia amazonica DC. (Myrtaceae), an endemic species to Brazil, widely distributed in the Amazonian, "Cerrado", and Atlantic Forest domains (Sobral et al. 2013) and commonly found in gallery forest and "campo rupestre" environments in the Chapada Diamantina, in contrast to other species preferentially restricted to a single habitat type. In gallery forests, $M$. amazonica is a lower canopy tree growing in the shade on deep soils, with abundant water resources throughout the year. In contrast, this same species appears as a shrub when growing in "campo rupestre" environments in narrow rock clefts on shallow soils and is exposed to low water availability and high solar radiation throughout the year.

The present study sought to evaluate variations in the morphofunctional characteristics associated with leaf phenology and water balance in populations of $M$. amazonica growing in gallery forest and "campo rupestre" habitats with contrasting irradiance and VPD. We investigated trade offs made by this species in terms of the costs-benefits of maintaining their foliage (phenology, leaf age, gas exchange, and photosynthetic pigments) and maintaining a positive water balance (water potential, wood density, leaf attributes) under the unique conditions found in those distinct habitats. We hypothesized that "campo rupestre" populations would experience high transpiration demands (as the vegetation there is open, receives elevated irradiance, and the thin, sandy mountain soils have only low water retention capacities) - and that those high demands would require stronger stomatal control as compared to individuals living in gallery forests. Additionally, we expected to observe greater efficiency of water use and lower wood densities in "campo rupestre" individuals, favoring the water storage capacity needed for adequate water potential control associated with maintaining its leaves for longer periods in "campo rupestre" vegetation rather than in gallery forests. 


\section{Material and methods}

Study area - The present study was undertaken in gallery forest and "campo rupestre" sites in the Chapada Diamantina mountain range in central Bahia State (BA) in northeastern Brazil. The gallery forest site $\left(12^{\circ} 33^{\prime} \mathrm{S} \times 41^{\circ} 24^{\prime} \mathrm{W}\right.$, at $400 \mathrm{~m}$ a.s.l.) was adjacent to the Lençóis River in the municipality of Lençóis-BA, occupying dystrophic soils, with humidity levels between 16 and $75 \%$ during the dry (June to October) and rainy (November to March) seasons, respectively (Funch et al. 2002, Miranda et al. 2011). The gallery forest canopy is continuous and composed of trees approximately $10 \mathrm{~m}$ tall, with emergent individuals reaching $20 \mathrm{~m}$; the understory is discontinuous and composed of vegetation from 3.5 to $8 \mathrm{~m}$ tall, composed principally of species of Myrtaceae and Melastomataceae. Myrtaceae is one of the richest and most abundant families in gallery forests (Funch et al. 2008), with many individuals of Myrcia amazonica D.C. varying between 4.5 and $8 \mathrm{~m}$ tall.

The "campo rupestre" site was located on the Morro da Mãe Inácia peak $\left(12^{\circ} 27^{\prime} \mathrm{S} \times 41^{\circ} 28^{\prime} \mathrm{W}\right.$, from 1000 to $1150 \mathrm{~m}$ a.s.l.) in the municipality of Palmeiras-BA, approximately $20 \mathrm{~km}$ in a straight line distance from the gallery forest along the Lençóis River. "Campo rupestre" is a complex vegetation type comprising numerous microhabitats on rocky mountain tops with varying conditions of water restrictions, soil nutrients, and soil depths that severely limit plant establishment and growth. The soils are sandy, usually thin, dystrophic neosols, between exposed rock surfaces (CPRM 1994). The specimens of $M$. amazonica studied there were encountered in a narrow cleft microhabitat of shrub-arboreal vegetation contained by rock walls. Myrtaceae is one of the five families with the greatest coverage in the "campo rupestre" habitat on the Morro da Mãe Inácia peak (Conceição et al. 2007). The individuals of $M$. amazonica studied were shorter than those of the gallery forest, reaching only $2 \mathrm{~m}$ in height.

The regional climate in the study area is type Aw by the Köppen climate classification (Alvares et al. 2013), with maximum rainfall in the austral summer (November to January) with a secondary peak of precipitation in March and April, characterizing a climate with rainy summers (between November and April) and dry winters (between June and October). The mean historical monthly precipitation in the region varies between $35 \mathrm{~mm}$ (July and August) to $184 \mathrm{~mm}$ (December), with average rainfall exceeding $100 \mathrm{~mm} / \mathrm{month}$ during the rainy season. Historical data of temperature and rainfall for the region and for the study period at the two sites are presented in Fig. 1. Weather data for the gallery forest were acquired from the meteorological station in the town of Lençóis, $1.5 \mathrm{~km}$ distant from our study site (furnished by the National
Institute of Meteorology-INMET); data for the "campo rupestre" site were gathered at a small meteorological station (Hobo 021-001) installed at the foot of that mountain, approximately $1 \mathrm{~km}$ from the study site. The VPD in the gallery forest varied from 1.41 to $1.78 \mathrm{kPa}$ during the driest month (October 2013) and from 0.35 to $1.85 \mathrm{kPa}$ during the rainiest month (April 2014). The VPD in the "campo rupestre" site varied from 1.12 to $4.19 \mathrm{kPa}$ during the driest month (October 2013) and from 0.58 to $0.97 \mathrm{kPa}$ during the rainiest month (April 2014). These data were obtained through measurements of temperature and relative humidity using a thermal hygrometer, employing the equations proposed by Jones (1992).

Leaf phenology - We marked ten individuals in each habitat, which were then accompanied on a monthly basis from October 2011 to April 2014. All of the measurements reported in this manuscript were taken only on those marked individuals. We observed the following phenophases: leaf flush (LF); young leaves (LY); mature leaves (LM); and leaf fall (LFF). Leaf flush was considered to be the emission of leaf buds; the young leaf stage was marked by expanding leaves, with lighter colorations than mature leaves; the mature leaf stage showed completely expanded leaves with dark colors; the leaf fall stage was marked by the presence of senescent leaves (brown and reddish colored) and branches without leaves. The intensities of the different stages were estimated during the field observations using a semiquantitative scale composed of five categories (0-4) with intervals of $25 \%$ between them, following the methodology described by Fournier (1974).

Leaf life span - Among the ten marked individuals, we accompanied 4 in each habitat (4 branches/individual) during the phenological observations (between October 2011 and April 2014) to determine leaf life spans. The branches and leaves were sketched on paper, noting existing leaves, with each new leaf being recorded and numbered. Monthly censuses were undertaken to record new leaf buds and the eventual disappearance of marked leaves. Leaf ages were calculated (in months) as the interval between leaf budding and leaf fall (Reich et al. 1991).

Leaf attributes - Collections of 10 fully expanded leaves from the 10 marked individuals in each habitat were made in December 2012, in February, August, and October 2013, and in January and April 2014 to determine dry leaf mass per unit area (LMA), and leaf succulence (SUC), thickness (LTH), and density (DEN). Leaf disks $\left(0.38 \mathrm{~cm}^{2}\right)$ were cut between the center vein and the leaf edge (using a cork borer) to determine those leaf attributes. The disks were soaked in distilled water for at least $24 \mathrm{~h}$ to measure their thicknesses (in mm, using a digital caliper) and their saturated masses (to $0.001 \mathrm{~g}$, using a precision electronic balance); the disks were then placed in a drying oven at 


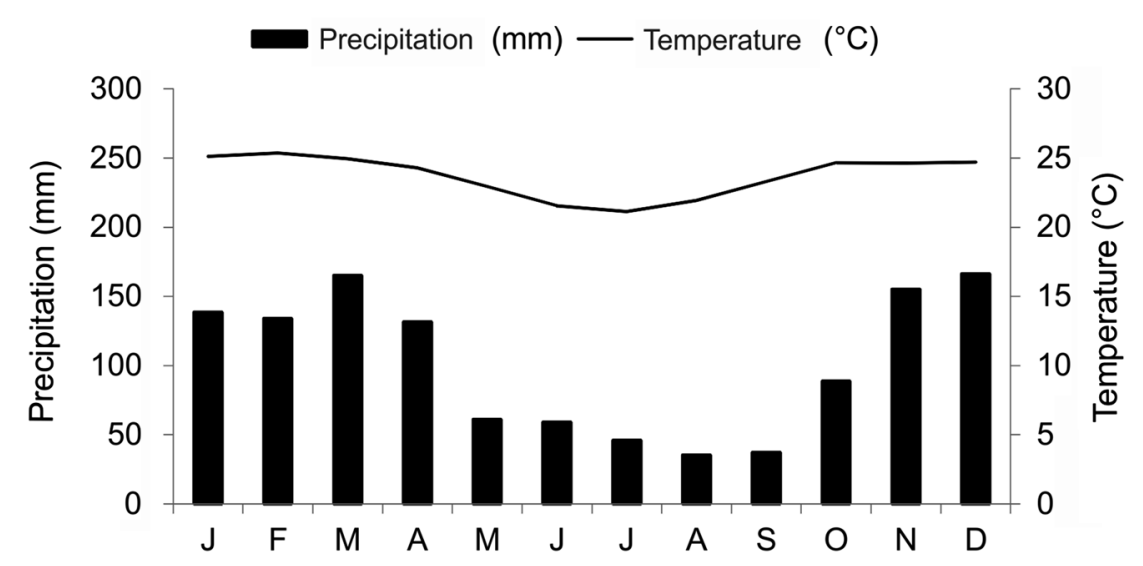

(a)

(b)
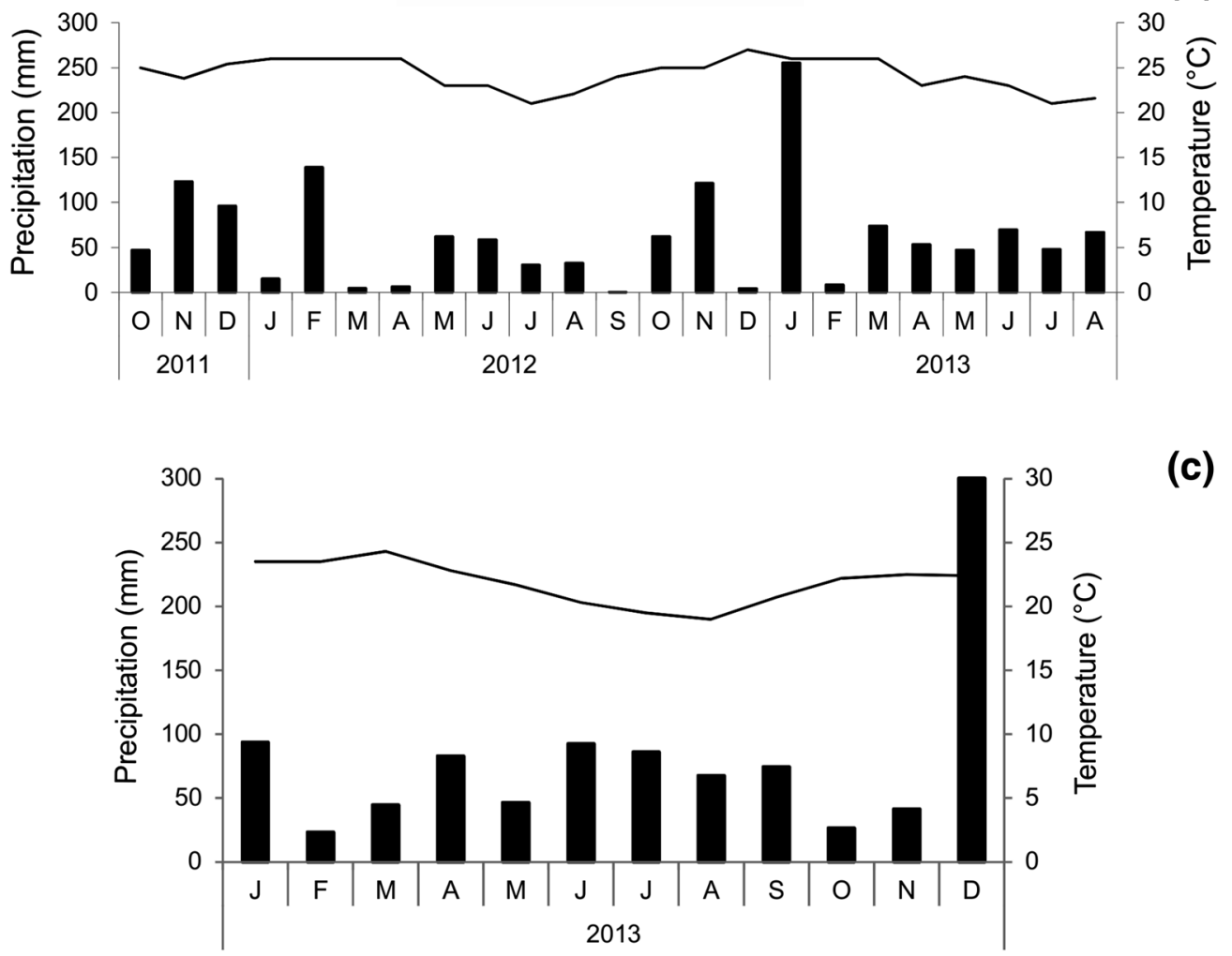

(c)

Fig. 1 Precipitation and temperature data for the region near Lençóis, Bahia State, Brazil. a Historical rates of precipitation and temperature during the period 1962-2013. b Total mean monthly precipitation (mm) and average monthly temperature $\left({ }^{\circ} \mathrm{C}\right)$ between October 2011 and April 2014. Source: Lençóis meteorological station, National Institute of Meteorology. c Total monthly precipitation (mm) and average monthly temperatures $\left({ }^{\circ} \mathrm{C}\right)$ during 2013. Source: Hobo 021-001 weather station at the Orquidário do Pai Inácio, Palmeiras

$55{ }^{\circ} \mathrm{C}$ for $72 \mathrm{~h}$ to obtain their dry masses. These values were used to calculate the SUC (the difference between the saturated and dry mass divided by the area of disks, in $\mathrm{g} \mathrm{cm}^{-2}$ ) and the LMA (dividing the dry mass by the disk area, in $\left.\mathrm{g} \mathrm{cm}^{-2}\right)$. The values of DEN $\left(\mathrm{mg} \mathrm{mm}^{-2}\right)$ were calculated using the formula: DEN $=$ LMA/LTH (Witkowski and Lamont 1991).

Wood density - Wood collections were made in January 2014; five samples approximately $10 \mathrm{~cm}$ long and
$3 \mathrm{~cm}$ in diameter were extracted from four marked individuals in each habitat (bark + heartwood + alburnum). The samples were immersed in distilled water for $72 \mathrm{~h}$ and then weighed to determine their saturated masses (Msat); their volumes (V) were determined using a 250-mL graduated cylinder containing distilled water. The core samples were then dried in a forced ventilation oven to a constant dry mass (Md) (Barbosa and Ferreira 2004). 
The resulting values were used to calculate wood density $\left(\mathrm{D}=\mathrm{Ms} V^{-1}\right)$ and the quantity of saturated water $\left(\mathrm{QWsat}=100(\right.$ Msat $\left.-\mathrm{Md}) \mathrm{Md}^{-1}\right)$, following Borchert (1994). The density classification followed the parameters described by Borchert (1994). A species was considered to have low wood density (LWD) when its density was $<0.5 \mathrm{~g} \mathrm{~cm}^{-3}$, and high wood density (HWD) when its density was $\geq 0.5 \mathrm{~g} \mathrm{~cm}^{-3}$.

Water potential - Water potentials $(\Psi)$ were measured in December 2012, February, August, and October 2013, and January and April 2014, using a Scholander pressure chamber (PMS model 1000), sampling three branches from the marked individuals (4 individuals/habitat); the collections were made using pruning shears. The branches were placed in plastic sacks immediately after cutting and stored in a cooler to minimize water losses. Two $\Psi \mathrm{W}$ measurements were taken with each individual during each day of monitoring: predawn ( $\left.\Psi_{\mathrm{PD}}\right)$ (between $04: 30 \mathrm{~h}$ and 05:30 h), in order to determine the maximum value at the start of the day; and a second measurement after midday $\left(\Psi_{\mathrm{PM}}\right)$ (between 12:30 and 13:30 hour), in order to determine the lowest daily potential. The amplitudes of the daily variations in water potential $(\Delta \Psi)$ were calculated using the formula $\Delta \Psi=\Psi_{\mathrm{PD}}-\Psi_{\mathrm{PM}}$.

Gas exchange - The maximum assimilation of $\mathrm{CO}_{2}$ $\left(A_{\max }\right)$, transpiration $(E)$, stomatal conductance $\left(g_{\mathrm{s}}\right)$ were determined in December 2012, February, August, and October 2013, and January and April 2014 using an infrared gas analyzer (ADC LCI) coupled to an artificial light source (LED, intensity $1500 \mu \mathrm{mol} \mathrm{m}^{-2} \mathrm{~s}^{-1}$ ). Measurements were taken on completely expanded leaves from four marked individuals of each species (four leaves per plant) at 09:00 in the two habitats examined. Water use efficiency (WUE) was determined by the ratio $A$ / $E$ (Larcher 2003).

Leaf photosynthetic pigments - To determine the levels of chlorophyll and carotenoids in the leaves, leaf disks $\left(0.38 \mathrm{~cm}^{2}\right)$ were cut from four marked individuals in each habitat (4 leaves/individual), from the same leaves and at the same times as the gas exchange measurements. The disks were cut into strips and placed in test tubes wrapped with aluminum foil containing $5 \mathrm{~mL}$ of dimethyl sulfoxide to extract their pigments. After $72 \mathrm{~h}$ in the dark, the extracts were analyzed in a spectrophotometer at 480, 649, and $665 \mathrm{~nm}$. The photosynthetic pigments were quantified using the equations described by Wellburn (1994) for chlorophyll a (Chlo a), chlorophyll b (Chlo b) and total chlorophyll (total Chlo), carotenoids (Car), chlorophyll a/b (Chlo a/b), and total chlorophyll/carotenoids (Chlo a + Chlo b)/Car).

Statistical analyses - The Shapiro-Wilk test (Zar 2010) was used to verify the normality of the data. Data not demonstrating normal distributions were nStatistical analysesatural log transformed (Zar 2010). To evaluate the plasticity of the morphofunctional characteristics of the populations, we calculated the phenotypic plasticity indices (PPI) of the variables LMA, SUC, LTH, DEN, $\Psi_{\mathrm{PD}}, \Psi_{\mathrm{PM}}$, $\Delta_{\Psi}$, wood density, saturated water, $A_{\max }, E$, WUE, $g_{s}$, Chlo a, Chlo b, Car, Chlo a/b, (Chlo a + Chlo b)/Car, and total Chlo following Valladares et al. (2000), where: PPI $=(-$ maximum-minimum)/maximum. An index of phenotypic plasticity (PPI) ranging from zero to one was calculated for each variable (Valladares et al. 2000). The PPI was calculated in the dry and rainy seasons in the two populations in order to determine which demonstrated more plasticity. Differences in the PPI index between populations were tested using an independent $t$-test. The variations of these parameters between the two populations were also compared using a multivariate repeated measure ANOVA using Statistica 7 software-considering all of the months together, as the measurements were always taken on the same individuals. We also performed analysis of variance followed by the Tukey Test $(P<0.05)$ to compare the means of the parameters related to leaf attributes, photosynthetic pigment contents, gas exchange, and water potential between the two populations during the study months (Zar 2010).

\section{Results}

Phenology and leaf life span - Leaf production by $M$. amazonica was annual in both populations studied (Fig. 2). We found differences in the timing, intensity, and duration of this phenophase, however, as the gallery forest showed increasing leaf flush and production of young leaves at the beginning of the rainy season, which prolonged until the end of that season. Leaf flush for individuals growing in the "campo rupestre" site occurred in a more intense manner for a shorter period during the transition between the dry and rainy seasons. Leaf fall was continuous, but not intense (maximal of 20\%), in both populations, which maintained their crowns in a continuous green state along the year. The greater reduction in the crown cover percentage by mature leaves in the "campo rupestre" site was related to a higher production of young leaves than to an actual leaf loss (Fig. 2). In the gallery forest, leaf life spans varied between 14 and 19 months (mean of $16 \pm 2.6$ months), while leaf life span in the "campo rupestre" varied between 13 and 21 months (mean of $18 \pm 3.1$ months), with those means differing significantly between the two populations (ANOVA: $d f=1, F=8.75, P=0.0001$ ).

Morphofunctional attributes - We found significant effects of the interaction between the time of year and population (Wilks $\lambda=0.2379, \quad F_{3.20}=21.34$ and $P<0.001$ ) in the morphofunctional attributes studied (see Appendix of ESM for univariate results). The attributes 

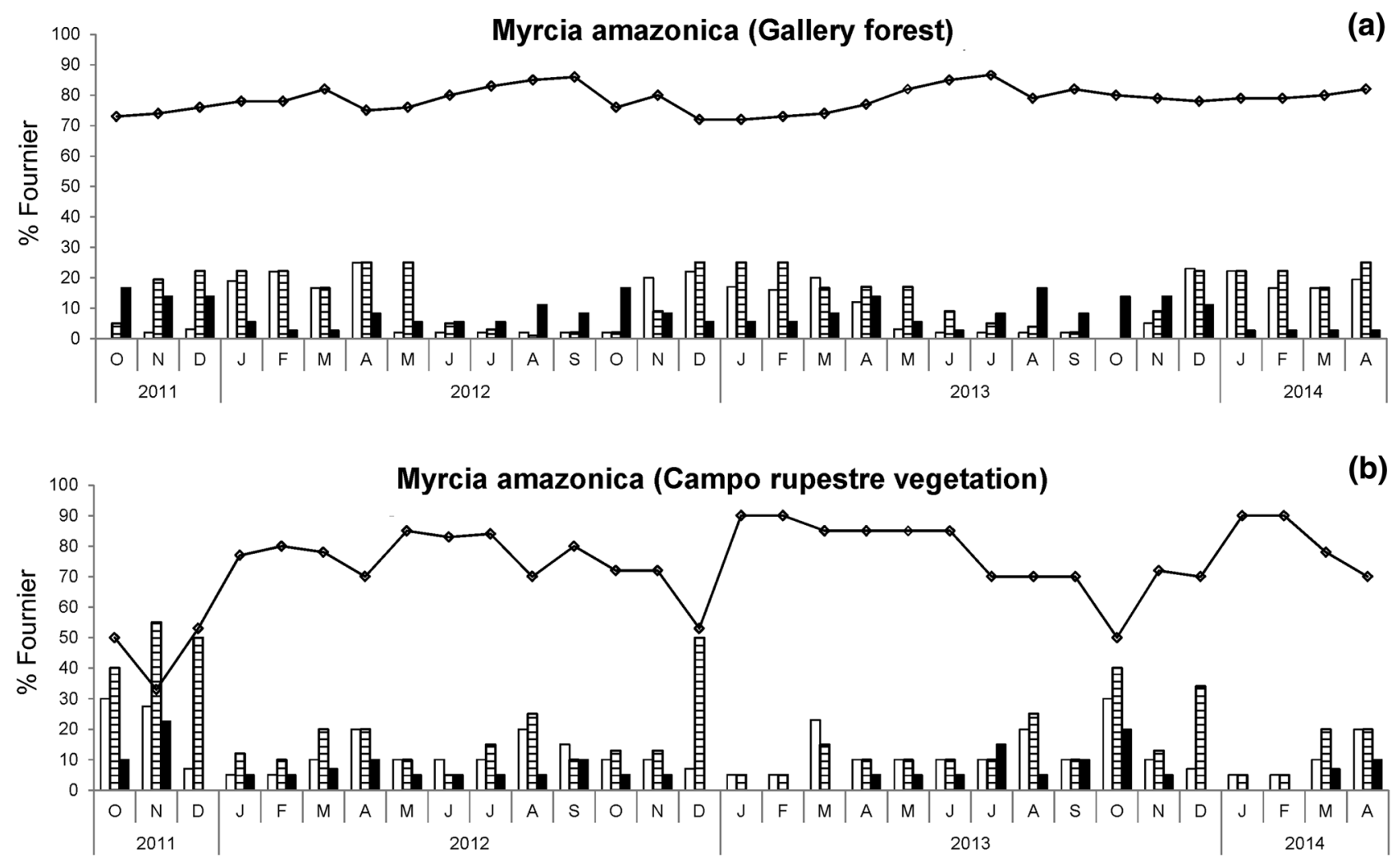

Fig. 2 Vegetative phenology of Myrcia amazonica in a gallery forest along the Lençóis River, Lençóis, and in "campo rupestre", Palmeiras, Chapada Diamantina, Bahia State, Brazil, for the period between October 2011 and April 2014. The graphs indicate leaf budding (white bars), young leaves (striped bars), mature leaves (lines with rhombuses), and leaf fall (black bars)

suffered influence of both the environment they were exposed to and the time of the year. The LMA of $M$. amazonica varied significantly between the two populations during the dry period $\left(F_{3.196}=66.46 P<0.01\right)$. SUC and LTH were significantly greater in "campo rupestre" plants $\left(F_{3.196}>15.00 P<0.01\right)$, while DEN was greater $\left(F_{3.196}=131.00 P<0.01\right)$ in the gallery forest site in all of the evaluations (Table 1). The gallery forest population generally demonstrated significantly higher levels $\left(F_{3.92}>5.00 P<0.01\right)$ of chlorophyll $a$ and $b$ and carotenoids as compared to the "campo rupestre" population (Table 1).

The maximum degrees of $\mathrm{CO}_{2}$ assimilation $\left(A_{\max }\right)$ and stomatal conductance $\left(g_{\mathrm{s}}\right)$ were higher in the "campo rupestre" population $\left(F_{3.28}>8.00 P<0.01\right)$. Transpiration $(E)$ followed the same pattern, except during the rainy period (Fig. 3). There were differences in WUE between the gallery forest and 'campo rupestre" populations during one month with a very low rainfall rate (October 2013) and during the rainy period (January and April 2014) when the plants responded to the increased availability of water provided by rainfall in the previous month, as was the case in January 2014.
The wood density was lower in the "campo rupestre" than in the gallery forest ("campo rupestre": $0.69 \pm 0.54$; gallery forest: $0.74 \pm 0.04)(P=0.001)$, while the opposite was observed in terms of the quantity of stored water in the saturated wood ("campo rupestre": $68.8 \%( \pm 4.19)$; gallery forest: $62.33( \pm 2.24)(P=0.0001)$. Significant differences between these populations were only observed in terms of the $\Psi_{\mathrm{PD}}$ of $M$. amazonica during the dry period (August and October 2013), with the individuals in the gallery forest showing the lowest values (Fig. 4). The $\Psi_{\mathrm{PM}}$ of the two populations varied during most of the evaluations, with "campo rupestre" individuals demonstrating the lowest values. The greatest daily amplitudes of water potential were recorded in the "campo rupestre" population (Fig. 4).

Essentially, all of the parameters evaluated demonstrated high phenotypic plasticity indices in both populations (Table 2). Although the functional responses of $M$. amazonica populations differed greatly between "campo rupestre" and gallery forest, there were no significant differences in their average PPI $(t=0.55 P=0.584$, $\mathrm{CR}=0.79$ and $\mathrm{GF}=0.75)$, suggesting similar degrees of variation in their functional traits. 


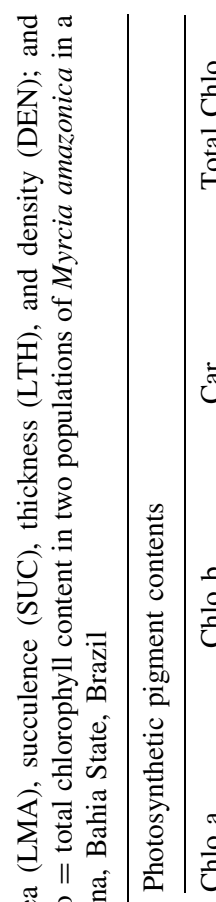

品 을

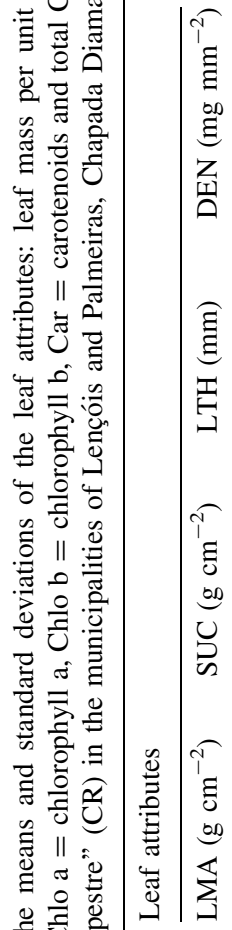

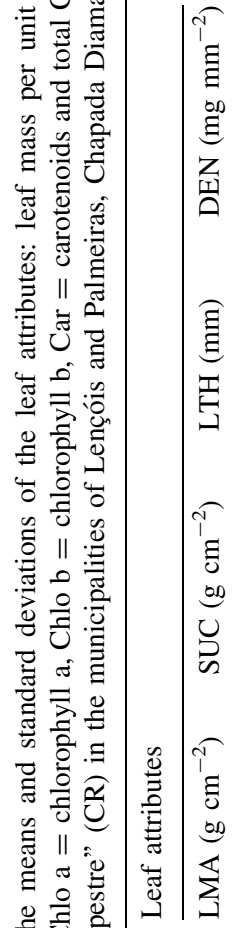

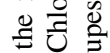

$\exists \ddot{\circ} 0$

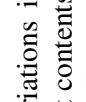

焉

要

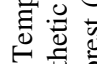

-

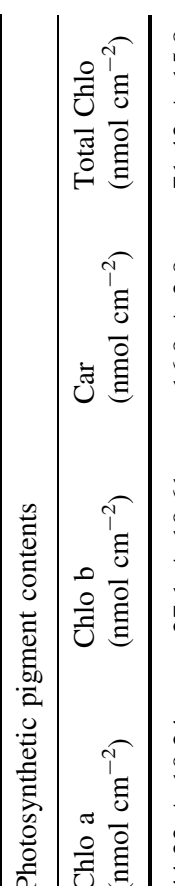

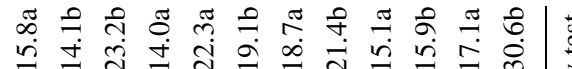

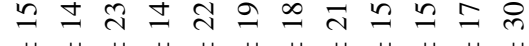
$\mathrm{H} H+H+H+H H C H H H H$

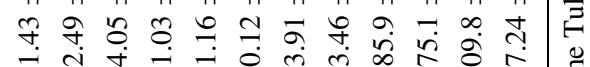

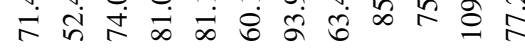

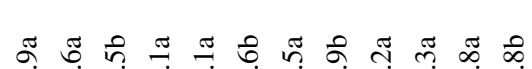

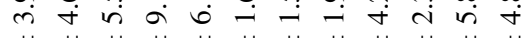
$\mathrm{H}+\mathrm{H} H+\mathrm{H} H \mathrm{H} H \mathrm{H} H \mathrm{H} H+\mathrm{H}$

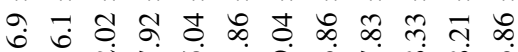

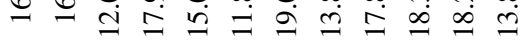

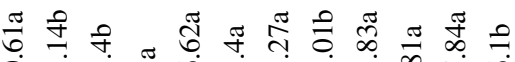

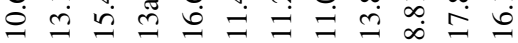
$\mathrm{H}+\mathrm{H} H \mathrm{H} H \mathrm{H}+\mathrm{H} H \mathrm{H}+\mathrm{H} H$

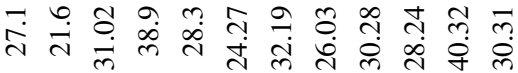

菅 오ำ

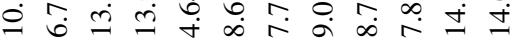
$\mathrm{H}+\mathrm{H} H+\mathrm{H} H \mathrm{H} H \mathrm{H} H+\mathrm{H} H$ กำ

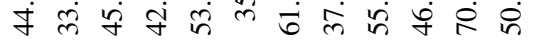

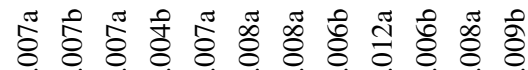

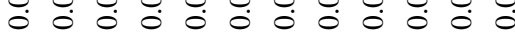
$H+H+H+H+H+H+H+H$

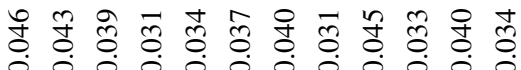

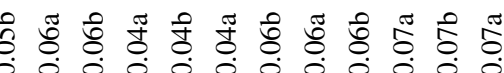

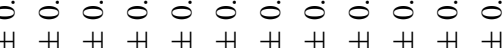

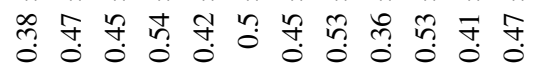

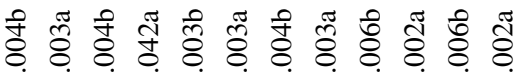

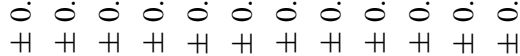

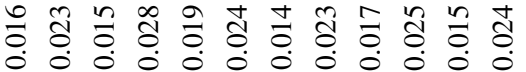

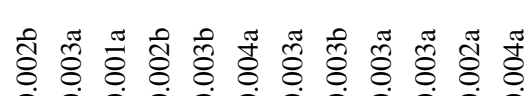

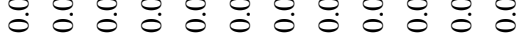
H H H H H H H H H H H H

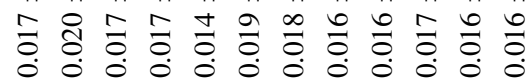

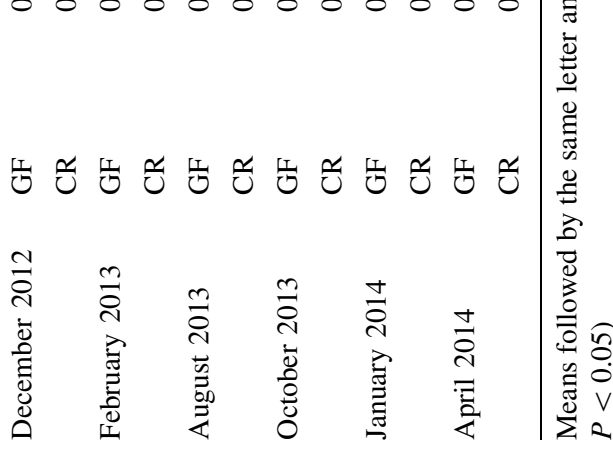



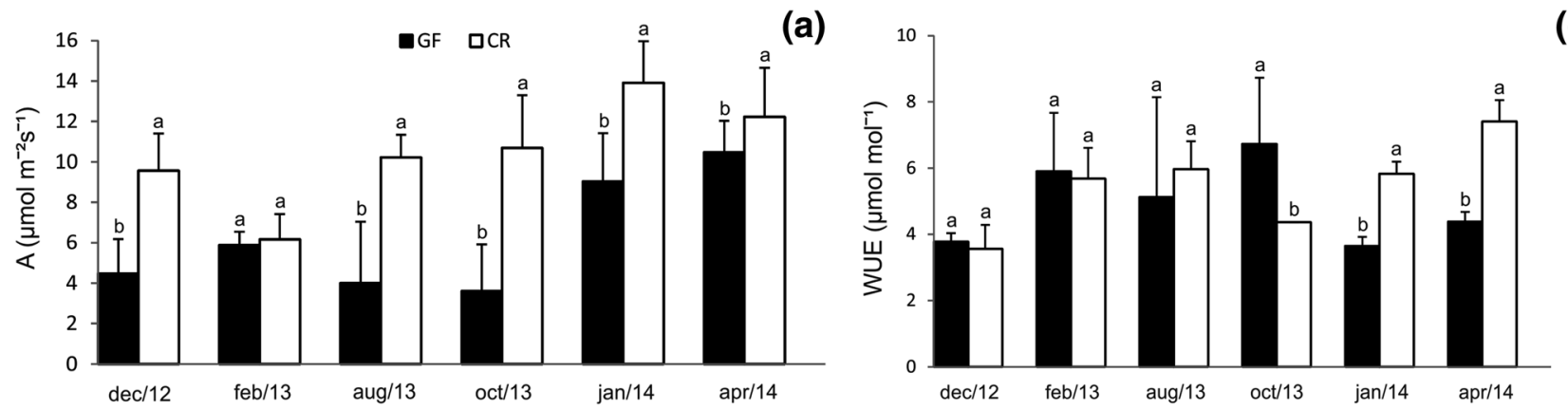

(c)

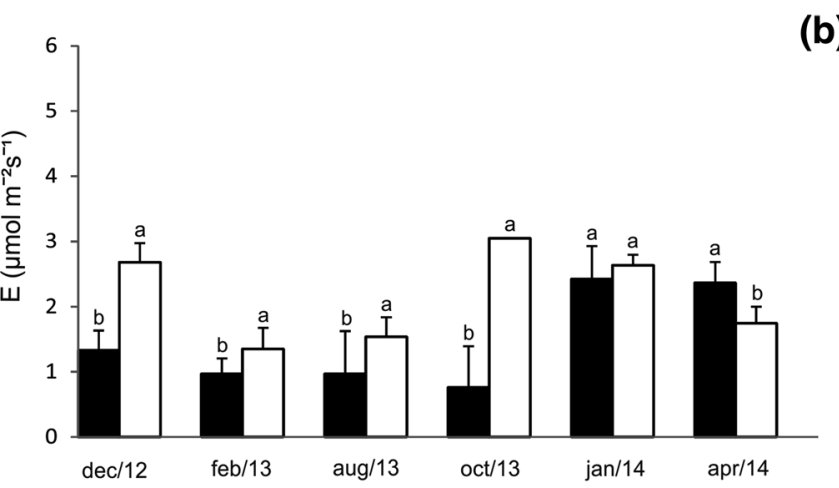

(b)

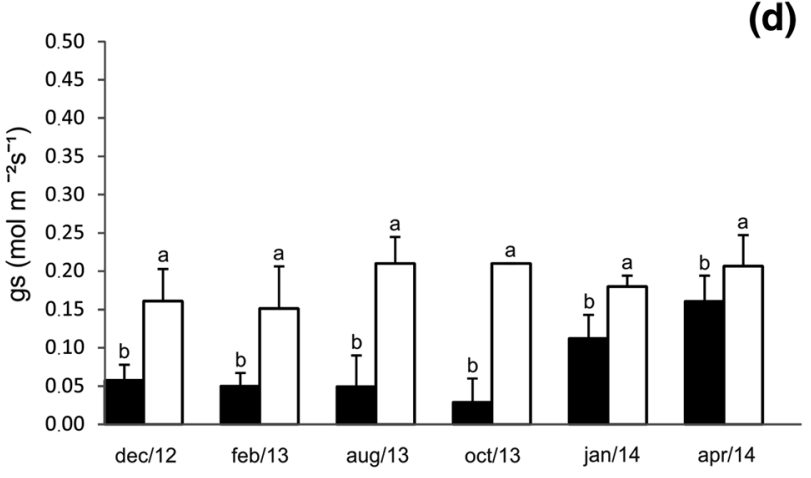

Fig. 3 Mean values and standard deviations of gas exchange in populations of Myrcia amazonica growing in a gallery forest (GF), Lençóis, and in "campo rupestre" (CR), Palmeiras, Chapada Diamantina, Bahia State, Brazil. A maximum rate of $\mathrm{CO}_{2}$ assimilation; $E$ transpiration; WUE water use efficiency; gs stomatal conductance. The graphs indicate measured values in gallery forest (black bars) and in "campo rupestre" (white bars). Means of populations followed by the same letter during each evaluation period indicate no statistically significant differences between them by the Tukey test $(P<0.05)$

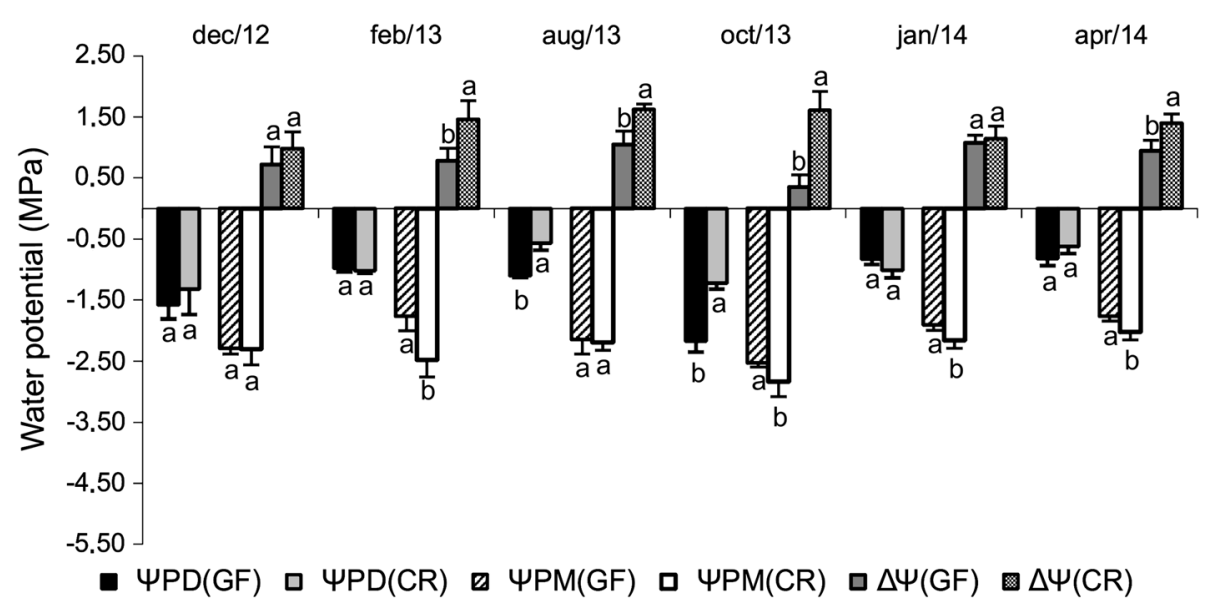

Fig. 4 Mean values and standard deviations of the water potentials in the morning $\left(\Psi_{\mathrm{PD}}\right)$, after midday $\left(\Psi_{\mathrm{PM}}\right)$, and the daily amplitudes of the water potentials $\left(\Delta_{\Psi}\right)$ of populations of Myrcia amazonica (Myrtaceae) growing in a gallery forest (GF), Lençóis, and in "campo rupestre" (CR), Palmeiras, Chapada Diamantina, Bahia State, Brazil. Means of the populations followed by the same letter during each evaluation period indicate no statistically significant differences between them by the Tukey test $(P<0.05)$

\section{Discussion}

Our results indicate the existence of significant functional and structural plasticity in M. amazonica. Phenotypic plasticity has been observed in different populations of a single species, reflecting adaptations to diverse microclimates in a series of habitats (Abbruzzese et al. 2009), as well as in different populations exposed to variations in irradiance in open or shaded habitats (even under otherwise similar climatic conditions) (Toledo et al. 2012; Valladares and Niinemets 2008; Vieira et al. 2015; Vitória et al. 2016). The phenotypic plasticity index (PPI) has been 
Table 2 Mean, maximum value (Max), minimum value (Min), and the phenotypic plasticity index (PPI) of 19 structural and physiological variables of Myrcia amazonica in gallery forest (GF) and "campo rupestre" (CR) populations in the municipalities of Lençóis and Palmeiras, Chapada Diamantina, Bahia State, Brazil

\begin{tabular}{|c|c|c|c|c|c|c|c|}
\hline Variable & Mean & Max-GF & Min-GF & Max-CR & Min-CR & PPI-GF & PPI-CR \\
\hline LMA $\left(\mathrm{g} \mathrm{cm}^{-2}\right)$ & 0.017 & 0.02 & 0.01 & 0.03 & 0.01 & 0.58 & 0.77 \\
\hline SUC $\left(\mathrm{g} \mathrm{cm}^{-2}\right)$ & 0.020 & 0.03 & 0.00 & 0.03 & 0.01 & 0.85 & 0.52 \\
\hline LTH (mm) & 0.46 & 0.59 & 0.27 & 0.69 & 0.34 & 0.54 & 0.51 \\
\hline $\mathrm{DEN}\left(\mathrm{mg} \mathrm{mm}^{-2}\right)$ & 0.038 & 0.07 & 0.02 & 0.06 & 0.02 & 0.67 & 0.70 \\
\hline$\Psi_{\mathrm{PD}}(\mathrm{MPa})$ & -1.12 & -0.9 & -2.3 & -0.35 & -1.45 & 0.61 & 0.76 \\
\hline$\Psi_{\mathrm{PM}}(\mathrm{MPa})$ & -2.21 & -1.1 & -2.6 & -1.8 & -3.3 & 0.58 & 0.45 \\
\hline$\Delta_{\Psi}(\mathrm{MPa})$ & 1.09 & 1.35 & 0.10 & 2.20 & 0.60 & 0.93 & 0.73 \\
\hline$A_{\max }\left(\mu \mathrm{mol} \mathrm{m} \mathrm{m}^{-2} \mathrm{~s}^{-1}\right)$ & 9.21 & 12.65 & 1.35 & 16.28 & 0.48 & 0.89 & 0.97 \\
\hline$E\left(\mu \mathrm{mol} \mathrm{m}{ }^{-2} \mathrm{~s}^{-1}\right)$ & 1.87 & 2.78 & 0.76 & 3.30 & 0.63 & 0.73 & 0.81 \\
\hline WUE $\left(\mu \mathrm{mol} \mathrm{mol}{ }^{-1}\right)$ & 4.77 & 13.54 & 2.35 & 8.45 & 2.38 & 0.83 & 0.72 \\
\hline$g_{\mathrm{s}}\left(\mathrm{mol} \mathrm{m} \mathrm{m}^{-2} \mathrm{~s}^{-1}\right)$ & 0.13 & 0.26 & 0.00 & 0.44 & 0.00 & 1.00 & 1.00 \\
\hline Chlo a $\left(\mathrm{nmol} \mathrm{cm} \mathrm{cm}^{-2}\right)$ & 48.52 & 88.54 & 6.86 & 89.30 & 20.37 & 0.92 & 0.77 \\
\hline Chlo b $\left(\mathrm{nmol} \mathrm{cm}^{-2}\right)$ & 29.86 & 96.60 & 14.31 & 92.89 & 8.48 & 0.85 & 0.91 \\
\hline $\operatorname{Car}\left(\mathrm{nmol} \mathrm{cm}{ }^{-2}\right)$ & 16.09 & 24.53 & 4.40 & 60.57 & 4.28 & 0.82 & 0.93 \\
\hline Chlo a/b & 1.76 & 3.30 & 0.70 & 2.66 & 0.11 & 0.79 & 0.96 \\
\hline$\left(\right.$ Chlo a + Chlo b)/Car $\left(\right.$ nmol cm $\left.{ }^{-2}\right)$ & 5.25 & 22.09 & 2.88 & 21.37 & 0.64 & 0.87 & 0.97 \\
\hline Total Chlo $\left(\mathrm{nmol} \mathrm{cm}^{-2}\right)$ & 78.38 & 182.40 & 40.56 & 162.00 & 14.30 & 0.78 & 0.91 \\
\hline
\end{tabular}

PPI-GF calculated between dry and rainy season in gallery forest; PPI-CR calculated between dry and rainy season in "campo rupestre"; $L M A$ leaf mass per unit area; $S U C$ leaf succulence; $L T H$ leaf thickness; $D E N$ leaf density; $\Psi_{\mathrm{PD}}$ water potential before dawn; $\Psi_{\mathrm{PM}}$ water potential after midday; $\Delta_{\Psi}$ daily amplitude of water potential; $A_{\max }$ maximum rate of $\mathrm{CO}_{2}$ assimilation; $E$ transpiration; $W U E$ water use efficiency; $g_{\mathrm{s}}$ stomatal conductance; Chlo a chlorophyll a; Chlo b chlorophyll b; Car carotenoids

used to better understand the capacity for plasticity in species and populations (Valladares et al. 2000). All of the parameters measured in the present study showed PPI above 0.61 -indicating high degrees of plasticity in $M$. amazonica populations.

Our data showed higher total chlorophyll and carotenoid concentrations in gallery forest plants, in contrast to low values in the "campo rupestre" population. This is the opposite of what might be expected for carotenoid levels in plants growing under sun and shade conditions. This elevated chlorophyll content was not reflected in higher A values in the gallery forest, however, which were lower than in "campo rupestre" (except in February 2013 when no differences between $\mathrm{A}$ for those populations were verified, as high total chlorophyll contents were detected in "campos rupestre" plants). It is possible that the higher irradiance conditions in "campo rupestre" promoted partial photooxidation of the photosynthetic pigments, as the data indicated (Table 1), but not enough to decrease A in this population as compared to the gallery forest (where lower irradiance was not compensated for by higher photosynthetic pigment concentrations). As incident irradiance is largely intercepted by the upper canopy in forests (Hogan and Machado 2012), the understory vegetation will be exposed to significantly lower light levels and show higher photosynthetic pigment contents (in general, chlorophyll b) and SLA (inverse of
LMA) in order to intercept more irradiation (Vitória et al. 2016). Varying levels of irradiance do occur within the crowns of individual trees, but greater amplitudes are usually observed among individuals growing under different environmental conditions (Vieira et al. 2015; Vitória et al. 2016).

The "campo rupestre" population of M. amazonica grows under higher irradiance conditions and demonstrated higher rates of stomatal conductance and photosynthesis as compared to the gallery forest population, suggesting irradiance as a limiting factor for photosynthetic activity in the latter. Variations in irradiance and transpirational demands can induce plasticity of stomatal conductivity and photosynthetic rates (Sultan 2000), as was observed in $M$. amazonica (Table 2).

The elevated photosynthetic rates observed in the "campo rupestre" population were reflected in the construction of thicker and more succulent leaves, with greater longevity. Leaves exposed to high solar irradiance tend to be thicker and may contain overlapping chloroplasts, as under such conditions those organelles would not experience light availability limitations that could negatively affect their photosynthetic production (Hogan and Machado 2012). These characteristics increase photosynthetic capacities and stomatal conductance (Gamage et al. 2003). Additionally, the high levels of SUC and LTH seen in M. amazonica reflect the species' capacity to store water 
in its leaves, a characteristic of plants that invest in the maintenance of a positive water balance and high rates of carbon acquisition (Rosado and de Mattos 2007) that aid survival in environments with intense irradiance.

The useful life of leaves must balance their construction costs, and while the production of young leaves requires considerable energy investments, they generally demonstrate higher photosynthetic rates (Kikuzawa and Lechowicz 2011). There are large differences between irradiance in the two habitats occupied by the two populations of M. amazonica, and the population growing in the "campo rupestre" site had leaves with longer life spans and greater photosynthetic rates. This reflects the fact that the metabolic price of growth includes not just the incorporation of dry weight material-but must also sum other metabolic activities such as respiration, which tends to be greater in environments with more exposure to irradiance (Larcher 2003), with correspondingly higher light compensation points.

The greater transpiration rate of the "campo rupestre" population resulted in greater water losses throughout the day, with consequently lower water potential values at midday (as compared to the gallery forest population). This did not present an insurmountable problem for the individuals growing in that environment, as they recuperated their water losses at night. The $\Psi_{\mathrm{PD}}$ value reflects the nocturnal ability of individuals to recuperate water lost during the day (Schmidhalter 1997; Wright and Cornejo 1999), and in many cases it can be an indicator of soil water availability (Andrade et al. 1998). In the populations of $M$. amazonica evaluated here, the $\Psi_{\mathrm{PD}}$ values were generally similar between the two populations. Similar results were reported for species growing in "cerrado rupestre" vegetation localities near "campo rupestre" stands (Moraes 2011) and for arboreal species in the same gallery forest examined here (Miranda et al. 2011).

The variations in amplitudes between water potential values in the early morning and those at midday $\left(\Delta_{\Psi}\right)$ are indicative of transpirational flux (Lemos Filho and Mendonça Filho 2000), and they tend to be more elevated when external factors influence transpiration and alter the pressure deficit of water vapor between the plant and the air (Larcher 2003). When the $\Psi$ was measured in the "campo rupestre" population under conditions with the highest VPD (recorded in October 2013), we observed an increase in the $\Delta_{\Psi}$ of that population. Correlations between $\Delta_{\Psi}$ and VPD were noted in research undertaken with Atlantic Forest (Lemos Filho and Mendonça Filho 2000) and "cerrado" (Franco et al. 2005) species, as well as with forest and savanna ecotypes (Toledo et al. 2012). These results indicated that when soil water availability was not a limiting factor, the evaporative demand of the air influenced daily plant water losses.
During the dry period, M. amazonica growing in the gallery forest showed significantly more negative $\Psi_{\mathrm{PD}}$ values than the "campo rupestre" population; they also showed the lowest $\Delta_{\Psi}$, even though they grew in an environment with a significantly lower VPD than observed in "campo rupestre". These variations reflect the phenological behavior of that species, with larger leaf fall occurring during the dry season in both populations. Another possibility is that the higher wood density of the gallery forest population does not allow as much water retention as the lower density wood of the "campo rupestre", requiring more water uptake to restore moisture levels in the gallery forest population. The higher competition in gallery forest sites and the more superficial roots expected in this environmental could also help explain the more negative $\Psi_{\mathrm{PD}}$ values observed there (mainly in the dry season). Additionally, the gallery forest population showed the highest WUE during this period-demonstrating the response capabilities of plants to environmental changes by adjusting their phenological dynamics, leaf longevity, water status, and gas exchange (Reich 1994).

Myrcia amazonica demonstrated high wood densities in both populations, although with slightly lower densities in "campo rupestre" sites-with consequent higher water storage capacities in the saturated wood of the latter (Borchert 1994). As such, even though it showed higher transpiration rates, the M. amazonica population growing in the "campo rupestre" site demonstrated similar water potential values to those of the gallery forest, favoring the maintenance of high photosynthetic rates in the former environment.

The small variations observed in the water potentials between the different habitats (with the exception of October 2013) appear to be related to morphological characteristics that influence plant water storage capacities. The population of M. amazonica growing in the "campo rupestre" had thicker and more succulent leaves and higher water storage capacity in its saturated wood. As such, even with greater transpiration rates, as compared to gallery forest plants, the "campo rupestre" population did not demonstrate exceptionally low water potential levels and was able to maintain a high photosynthetic rate. The populations of M. amazonica demonstrated seasonal variations in their $\Psi$, suggesting anisohydric behavior, exhibiting stomatal sensitivity to seasonal evaporative demands and soil humidity without, however, show rigid control of $\Psi$ during the year (Martinez-Vilalta et al. 2014; Braga et al. 2016). In addition to the extremes of isohydry (plants whose tight control of transpiration allows constant seasonal $\Psi$ values) and anisohydry, a third manner of water status regulation was proposed based on the premise that anisohydric species can also demonstrate isohydrodynamic behavior. In that model, in spite of seasonal variations in 
$\Psi$, greater water restrictions are apparent at midday $\left(\Psi_{\mathrm{PM}}\right)$ especially in the driest months; this type of behavior was observed in M. amazonica, independent of the environment investigated.

In conclusion, the data presented here demonstrates that even with large variations in leaf attributes and daily water potential variations, the two populations of $M$. amazonica maintained perennial leaf patterns (despite with variations in the intensity and duration of leaf production). Myrcia amazonica exhibited sufficiently high functional and structural plasticity within its adaptive spectrum for successful establishment and growth in habitats with differing levels of water availability and irradiance.

Acknowledgements The authors would like to thank the Postgraduate Program in Botany/Universidade Estadual de Feira de Santana for providing the necessary infrastructure for the monthly collections and the experiments undertaken and the Conselho Nacional de Desenvolvimento Científico e Tecnológico (305333/2009-7) and the Fundação de Amparo à Pesquisa do Estado da Bahia (5303/2009) for their financial support. A.C.S.M. was supported by Coordenação de Aperfeiçoamento de Pessoal de Nível Superior (CAPES) Grant and A.P.V. by a CNPq Pq Grant (306758/2013-0).

\section{References}

Abbruzzese G, Beritognolo I, Muleo R, Piazzai M, Sabatti M, Mugnozza GS, Kuzminsky E (2009) Leaf morphological plasticity and stomatal conductance in three Populus alba L. genotypes subjected to salt stress. Environ Exp Bot 66:381-388. doi:10.1016/j.envexpbot.2009.04.008

Alvares CA, Stape JL, Sentelhas PC, Gonçalves JLM, Sparovek G (2013) Köppen's climate classification map for Brazil. Meteorol Z 22:711-728

Andrade JL, Meinzer FC, Goldstein G, Holbrook NM, Cavelier J, Jackson D, Silvera K (1998) Regulation of the water flux throughout trunks, branches and leaves in trees of a lowland tropical forest. Oecologia 115:463-471. doi:10.1007/ s004420050542

Barbosa RI, Ferreira CA (2004) Densidade básica da madeira de um ecossistema de "campina" em Roraima, Amazônia Brasileira. Acta Amazon 34:587-591

Bloor JMG, Grubb PJ (2004) Morphological plasticity of shadetolerant tropical rainforest tree seedlings exposed to light changes. Funct Ecol 18:337-348. doi:10.1111/j.0269-8463.2004

Boardman NK (1977) Comparative photosynthesis of sun and shade plants. Annu Rev Plant Physiol 28:355-377. doi:10.1146/ annurev.pp.28.060177.002035

Borchert R (1994) Soil and stem water storage determine phenology and distribution of tropical dry forests trees. Ecology 75:1437-1449

Braga N, Vitória AP, Souza G, Barros C, Freitas L (2016) Weak relationships between leaf phenology and isohydric and anisohydric behavior in lowland wet tropical forest trees. Biotropica 48:453-464

Capuzzo JP, Rossatto DR, Franco AC (2012) Differences in morphological and physiological leaf characteristics between Tabebuia aurea and T. impetiginosa is related to their typical habitats of occurrence. Acta Bot Bras 26:519-526
Chazdon RL (1986) Light variation and carbon gain in rain forest understory palms. J Ecol 74:995-1012

Chen HYH, Klinka K (1997) Light availability and photosynthesis of Pseudotsuga menziesii seedlings grown in the open and the forest understory. Tree Physiol 17:23-29

Choat B, Jansen S, Brodribb TJ, Cochard H, Delzon S, Bhaskar R, Bucci SJ, Feild TS, Gleason SM, Hacke UG, Jacobsen AL, Lens F, Maherali H, Martínez-Vilalta J, Mayr S, Mencuccini M, Mitchell PJ, Nardini A, Pittermann J, Pratt RB, Sperry JS, Westoby M, Wright IJ, Zanne AE (2012) Global convergence in the vulnerability of forests to drought. Nature 491:752-756. doi:10.1038/nature 11688

Conceição AA, Funch LS, Pirani JR (2007) Reproductive phenology, pollination and seed dispersal syndromes on sandstone outcrop vegetation in the "Chapada Diamantina", northeastern Brazil: population and community analyses. Rev Bras Bot 30:475-485

Companhia de Pesquisa de Recursos Minerais - CPRM (1994) Projeto Chapada Diamantina, Parque Nacional da Chapada Diamantina-BA: Informações básicas para a gestão territorial-diagnóstico do meio físico e da vegetação. CPRM, Salvador

Fournier LA (1974) Un método cuantitativo para la medición de características fenológicas en árboles. Turrialba 2:422-423

Franco AC, Bustamante M, Caldas LS, Goldstein G, Meinzer FC, Kozovits AR, Rundel P, Coradin VTR (2005) Leaf functional traits of Neotropical savanna trees in relation to seasonal water deficit. Trees 19:326-335

Funch LS, Funch R, Barroso GM (2002) Phenology of gallery and montane forest in the Chapada Diamantina, Bahia, Brazil. Biotropica 34:40-50

Funch LS, Rodal MJN, Funch RR (2008) Floristic aspects of forests of the Chapada Diamantina, Bahia, Brazil. In: Thomas W, Britton EG (eds) The coastal forests of Northeastern Brazil. Springer and NYBG Press, New York, pp 193-220

Funch RR, Harley RM, Funch LS (2009) Mapping and evaluation of the state of conservation of the vegetation in and surrounding the Chapada Diamantina National Park, NE Brazil. Biota Neotrop 9:21-30

Gamage HK, Hashton MS, Singhakumara BMP (2003) Leaf structure of Syzygium spp. (Myrtaceae) in relation to site affinity within a tropical rain forest. Bot J Linn Soc 141:365-377

Ganie AH, Reshi ZA, Wafai BA, Puijalon S (2014) Phenotypic plasticity: cause of the successful spread of the genus Potamogeton in the Kashmir Himalaya. Aquat Bot 120:283-289

Goulart MF, Lemos Filho JP, Lovato MB (2005) Phenological variation within and among populations of Plathymenia reticulata in Brazilian Cerrado, the Atlantic Forest and transitional sites. Ann Bot 96:445-455

Hogan KP, Machado JL (2012) La luz solar: consecuencias biológicas y medición. In: Guariguata MR, Kattan GH (eds) Ecología y conservación de Bosques Neotropicais. Editorial tecnológica de Costa Rica, Cartago, pp 119-143

Jones HG (1992) Plants and microclimate: a quantitative approach to environmental plant physiology, 2nd edn. Cambridge University Press, New York

Kikuzawa K, Lechowicz MJ (2011) Ecology of leaf longevity. Springer, New York

Larcher W (2003) Physiological plant ecology, 4th edn. Springer, New York

Lemos Filho JP, Goulart MF, Lovato MB (2008) Populational approach in ecophysiological studies: the case of Plathymenia reticulata, a tree from Cerrado and Atlantic Forest. Braz J Plant Physiol 20:205-216

Lemos Filho JP, Mendonça Filho CV (2000) Seasonal changes in the water status of three woody legumes from the Atlantic forest, Caratinga. Braz J Trop Ecol 16:21-32 
Martinez-Vilalta J, Poyatos R, Aguad DE, Retana J, Mencuccini M (2014) A new look at water transport regulation in plants. New Phytol 204:105-115

McCulloh KA, Johnson DM, Petitmermet J, McNellis B, Meinzer FC, Lachenbruch B (2015) A comparison of hydraulic architecture in three similarly sized woody species differing in their maximum potential height. Tree Physiol 35:723-731

Meinzer FC, Johnson DM, Lachenbruch B, McCulloh KA, Woodruff DR (2009) Xylem hydraulic safety margins in woody plants: coordination of stomatal control of xylem tension with hydraulic capacitance. Funct Ecol 23:922-930

Miranda LAP, Vitória AP, Funch LS (2011) Leaf phenology and water potential of five arboreal species in gallery and montane forests in the Chapada Diamantina; Bahia. Braz Environ Exp Bot 70:143-150

Moraes ACS (2011) Fenologia, síndromes de polinização e dispersão e potencial hídrico de espécies lenhosas de cerrado, Chapada Diamantina, Bahia, Brasil. Masters Thesis. Universidade Estadual de Feira de Santana, Bahia

Murchie EH, Horton P (1997) Acclimation of photosynthesis to irradiance and spectral quality in British plant species: chlorophyll content, photosynthetic capacity and habitat preference. Plant Cell Environ 20:438-448

Naramoto M, Katahata S, Mukai Y, Kakubari Y (2006) Photosynthetic acclimation and photoinhibition on exposure to high light in shade-developed leaves of Fagus crenata seedlings. Flora 201:120-126

Neves SPS, Funch R, Conceição AA, Miranda LAP, Funch LS (2016) What are the most important factors determining different vegetation types in the Chapada Diamantina, Brazil. Braz J Biol 76:315-333. doi:10.1590/1519-6984.13814

Pockman WT, Sperry JS, O'Leary JW (1995) Sustained and significant negative water pressure in xylem. Nature 378:715-716

Puglielli G, Crescente MF, Frattaroli AR, Gratani L (2015) Leaf mass per area (LMA) as a possible predictor of adaptive strategies in two species of Sesleria (Poaceae): analysis of morphological, anatomical and physiological leaf traits. Ann Bot Fenn 52:135-143

Reich PB, Uhl C, Walters MB, Ellsworth DS (1991) Leaf lifespan as a determinant of leaf structure and function among 23 tree species in Amazonian forest communities. Oecologia 86:16-24

Reich PB (1994) Phenology of tropical forest: patterns, causes, and consequences. Can J Bot 73:141-159

Rodríguez-Garcia E, Bravo F (2013) Plasticity in Pinus pinaster populations of diverse origins: comparative seedling responses to light and Nitrogen availability. For Ecol Manage 307:196-205. doi:10.1016/j.foreco.2013.06.046

Rosado BHP, de Mattos EA (2007) Variação temporal de características morfológicas de folhas em dez espécies do Parque Nacional da Restinga de Jurubatiba, Macaé, RJ, Brasil. Acta Bot Bras 21:741-752

Rosado BHP, Dias ATC, de Mattos EA (2013) Going back to basics: importance of ecophysiology when choosing functional traits for studying communities and ecosystems. Natureza Conservação $11: 15-22$

Rossato DR (2013) Seasonal patterns of leaf production in cooccurring trees with contrasting leaf phenology: L time and quantitative divergences. Plant Species Biol 28:138-145. doi:10. 1111/j.1442-1984.2012.00373.x

Rossatto DR, Hoffmann WA, Silva LCR, Haridasan M, Sternberg LSL, Franco AC (2013) Seasonal variation in leaf traits between congeneric savanna and forest trees in Central Brazil: implications for forest expansion into savanna. Trees 27:1139-1150
Sanchez A, Smith WK (2015) No evidence for photoinhibition of photosynthesis in alpine Caltha leptosepala DC. Alp Bot 125:41-50. doi:10.1007/s00035-015-0146-2

Sinclair RT, Zwieniecki MA, Holbrook NM (2008) Low leaf hydraulic conductance associated with drought tolerance in soybean. Physiol Plant 132:446-451. doi:10.1111/j.1399-3054. 2007.01028.x

Singh KP, Kushwaha CP (2005) Emerging paradigms of tree phenology in dry tropics. Curr Sci 89:964-975

Schmidhalter U (1997) The gradient between pre-dawn rhizoplane and bulk soil matric potentials, and its relation to the pre-dawn root and leaf water potentials of four species. Plant Cell Environ 20:953-960

Sobral M, Proença C, Souza M, Mazine F, Lucas E (2013) Myrtaceae. In: Lista de Espécies da Flora do Brasil. Rio de Janeiro: Jardim Botânico do Rio de Janeiro. Disponível em. http://floradobrasil. jbrj.gov.br/jabot/floradobrasil/. Accessed 12 July 2015

Souza GM, Sato AM, Ribeiro RV, Prado CHBA (2010) Photosynthetic responses of four tropical tree species grown under gap and understorey conditions in a semi-deciduous forest. Braz $\mathrm{J}$ Bot 33:529-538. doi:10.1590/S0100-84042010000400002

Sperry JS (2000) Hydraulic constraints on plant gas exchange. Agric For Meteorol 104:13-23

Sultan SE (2000) Phenotypic plasticity for plant development, function and life history. Trends Plant Sci 5:537-542

Toledo MM, Paiva EAS, Lovato MB, Lemos Filho JP (2012) Stem radial increment of forest and savanna ecotypes of a Neotropical tree: relationships with climate, phenology, and water potential. Trees 26:1137-1144. doi:10.1007/s00468-012-0690-y

Valladares F, Wright SJ, Lasso E, Kitajima K, Pearcy RW (2000) Plastic phenotypic response to light of 16 congeneric shrubs from a Panamanian rainforest. Ecology 81:1925-1936

Valladares F, Niinemets U (2008) Shade tolerance, a key plant feature of complex nature and consequences. Annu Rev Ecol Evol Syst 39:237-257

Vieira TO, Degli-Espoti MSO, Souza GM, Rabelo GR, da Cunha M, Vitória AP (2015) Photoacclimation capacity in seedling and sapling of Siparuna guianensis (Siparunaeae): response to irradiance gradient in tropical forest. Photosynthetica 53:11-22. doi:10.1007/s11099-015-0073-x

Vitória AP, Vieira TO, Plinio BC, Santiago LS (2016) Using leaf $\delta 13 \mathrm{C}$ and photosynthetic parameters to understand acclimation to irradiance and leaf age effects during tropical forest regeneration. For Ecol Manage 379:50-60

Wellburn AR (1994) The spectral determination of chlorophylls a and $\mathrm{b}$, as well as total carotenoids, using various solvents with spectrophotometers of different resolution. J Plant Physiol 144:307-313

Witkowski ETF, Lamont BB (1991) Leaf specific mass confounds leaf density and thickness. Oecologia 88:486-493

Wortemann R, Herbette S, Barigah TS, Fumanal B, Alia R, Ducousso A, Gomory D, Roeckel-Drevet P, Cochard H (2012) Genotypic variability and phenotypic plasticity of cavitation resistance in Fagus sylvatica L. across Europe. Tree Physiol 31:1175-1182. doi:10.1093/treephys/tpr101

Wright SJ, Cornejo FH (1999) Seasonal drought and leaf fall in a tropical forest. Ecology 71:1165-1175

Xue Q, Weiss A, Arkebauer TJ, Baenziger SP (2004) Influence of soil water status and atmospheric vapor pressure deficit on leaf gas exchange in field-grown winter wheat. Environ Exp Bot 51:167-179

Zar JH (2010) Biostatistical analysis, 5th edn. Prentice-Hall, New Jersey 